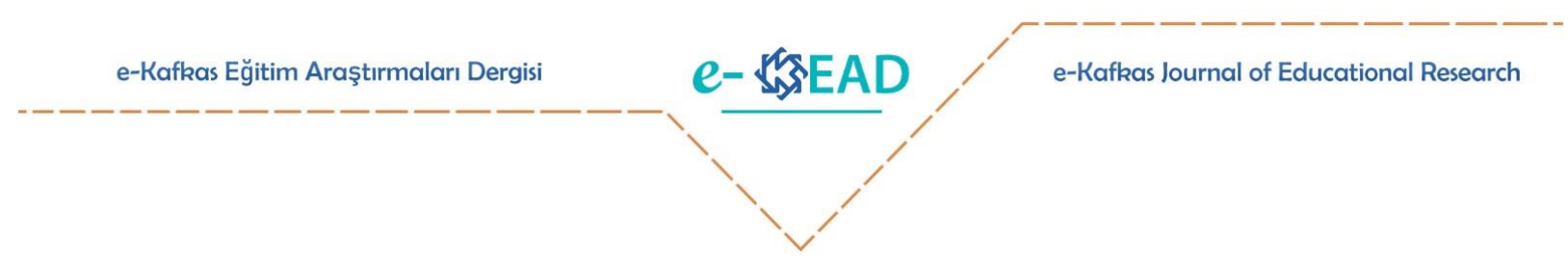

\title{
Okul Sözlüklerinin Biçimsel-İ̧erik Özellikleri ve Akademik Çalışmalarda Değinilen Sorunlar Bağlamında Türkçe Okul Sözlüğü Hazırlama Süreç, İlke ve Ölçütleri Üzerine Bir Öneri: Tematik Okul Sözlükleri*
}

\begin{abstract}
Ali Göçer (1) 凶
Atıf: Göçer, A. (2020). Okul sözlüklerinin biçimsel-içerik özellikleri ve akademik çalışmalarda değinilen sorunlar bağlamında Türkçe okul sözlüğü hazırlama süreç, ilke ve ölçütleri üzerine bir öneri: Tematik okul sözlükleri. e- Kafkas Eğitim Araşstırmaları Dergisi, 7, 66-83. doi: 10.30900/kafkasegt.686488

Derleme Makalesi

Geliş Tarihi: 07.02.2020

Kabul Tarihi: 01.04.2020

$\ddot{O} z$

Bugün her alanda olduğu gibi eğitim alanında da gelişim, değişim ve dönüşümün hızlı bir şekilde gözlemlenmektedir. Günümüz dünyasında ihtiyaç duyulan bilgiye başvurma, ulaşılan bilgiyi ayıklayıp süzme, transfer etme, var olan bilgi ile harmanlayarak yeni bilgi üretme ve en önemlisi de sahip olunan bilginin yerli yerince kullanılarak gereken becerileri sergileyebilme en öncelikli yetkinlikler arasındadır. Bilginin sürekli değiştiği bir zaman diliminde bilgi üretme ve üretilen bilginin gerçek yaşamda kullanılabilme yeterliği bireyin anlama, anlamlandırma, çıkarımda bulunma ve kavrama becerilerinin etkin kullanabilmesini de gerekli kılmaktadır. Anlama ve anlatma becerilerinin alt yapısını oluşturan temel güç, sahip olunan söz varlı̆̆ıdır. Söz varlı̆̆ının zenginleştirilmesinde ise eğitim süreçlerinde kullanılan eğitim materyalleri önemli işlev görmektedir. $\mathrm{Bu}$ materyallerden en işlevsel ve yaygın kullanılanı kelime dağarcığını zenginleştirmede başvurulan sözlüklerdir. Öğrencilerin zengin bir kelime dağarcığına sahip olmalarında temel başvuru kaynağı okul sözlükleridir. Okul sözlükleri pedagojik bir araç olarak geçmişten günümüze kullanılagelen ilk ve temel başvuru kaynaklarındandır. Eğitim kademelerinin ilkinden başlamak üzere her düzeyde eğitsel işlev gören bilgi kaynağı ve birtakım dilsel ve zihinsel beceriler kazandıran başvuru aracıdır. Eğitim sürecinde temel başvuru araçlarından olan sözlüklerin eğitsel değere sahip işlevsel bir araç olabilmesi için birtakım özelliklere sahip olması gerekir. Bu çalışmada okul sözlüklerinin eğitim bilimsel bağlamda yapısı, işlevselliği, özellikleri ve hazırlama ölçütleri üzerinde durulmakta, tematik yapıda ilk, orta ve lise düzeyinde kullanılabilecek ardışık okul sözlüğünün hazırlanması önerilmektedir.
\end{abstract}

Anahtar Sözcükler: Dil eğitimi, söz dağarcığı, sözlük, okul sözlükleri hazırlama ilke ve ölçütleri.

\begin{abstract}
As in every field, development, change, and transformation are rapidly observed in the field of education. It is among the top priority competencies to use the information needed, to extract and filter the information obtained, to transfer, to produce new information by blending with the existing information, and most importantly, to display the skills required by using the knowledge locally. The ability to produce information in a time when information is constantly changing and the ability to use the produced information in real life also requires the individual to use the skills of understanding, interpretation, inference and comprehension effectively. The basic power forming the basis of comprehension and expression skills is the vocabulary possessed. In the enrichment of vocabulary, educational materials play an important role. The most functional and widely used of these materials are dictionaries. School dictionaries are the main source of reference for students to have a rich vocabulary knowledge. They are one of the first and main reference sources used from past to present as a pedagogical tool. Starting from the first educational level, it is an information source serving educational functions at all levels and an application tool providing some linguistic and mental skills. Dictionaries must have some features to be a functional tool with educational value. This study focuses on the structure, functionality, features and preparation criteria of the school dictionaries, and preparing a consecutive school dictionary that can be used in the thematic structure is recommended at the primary, middle and high school levels.
\end{abstract}

Keywords: Language education, vocabulary, dictionary, principles and criteria of preparing school dictionaries.

* Bu çalışma 25 Ekim 2019 tarihinde Türk Dil Kurumu Başkanlığında düzenlenmiş olan 'Okul Sözlükleri Çalışma

Toplantısı'nda sözlü olarak sunulmuştur. 


\section{Giriş}

İnsanlar duygu, düşünce, hayal, istek ve tasarılarını başkalarıyla paylaşmak; yaşanmışlıklarını, yaşayamadıklarını kalıcı kılabilmek için yazma ihtiyacı duyarlar ve bu ihtiyacı temel iletişim aracı olan dili kullanarak karşılarlar. Dil, yaşamın her anında insanların işini kolaylaştıran vazgeçilmez bir araçtır.

Dilin olmazsa olmazlığını sağlayan tüm işlevlerini yerine getirmesinde en etkili unsur ise o dile ait kelime kadrosunun yeterliğidir. Bir dile ait kelimeleri günlük yaşamda aktif bir şekilde kullanma oranı ne kadar yüksekse, o dili konuşan bireylerin dili kullanabilme yeterliği, iletişim becerisi ve yaşam kalitesi de o oranda yüksek olur. Göçer'e (2009) göre de dilin doğru ve etkili kullanılabilmesinde sahip olunan söz varlığı önemi büyüktür.

Eğitim alanından sosyal hayata, bir mesleği icra etmeden, bir ihtiyacı gidermeye kadar insana hemen her alanda gerekli olan anlama ve anlatma becerileri, dili ayakta tutan iki temel sütun olup dinleme, konuşma, okuma ve yazma becerileriyle ayakları yer tutar. Canlı bir varlık olan dilin omurgası bu becerilerle oluşur. Dilin bu temel becerilerine işlevsellik katan, omurgaya hareket etme firsatı vererek incelik ve güzellikleri sergilemesinde başvurulan temel yapıtaşları ise o dilin söz varlığıdır. $\mathrm{Bu}$ bakımdan bir dilin imkânları ve sınırlılıkları söz varlığının sınırlarıyla doğru orantılıdır.

Günümüz dünyasında bilgi sahibi olmak, sahip olunan bilgiyi yeri ve zamanı geldikçe kullanabilmek önemlidir. Bilginin gerçek yaşam ortamlarında beceri olarak kendini göstermesi, bireyin anlama, anlamlandırma ve anlatma becerilerini kullanabilme yeterliğiyle ilgilidir. Anlama ve anlatma becerilerinin alt yapısını oluşturan temel güç, sahip olunan söz varlığıdır. Bireyin söz varlı̆̆ının zenginleştirilmesinde eğitsel değere sahip en temel araç ise sözlüklerdir. İlkokuldan itibaren pedagojik bir araç olarak tüm eğitim sürecinde bir başvuru kaynağı olarak kullanılan sözlükler, içerdiği sözcüklerle anlamadan anlatmaya, iletişimden işbirliğine gerçek yaşamda gerekli birçok yetkinlik açısından başvurulacak bir rezerv alan zenginliğine sahiptir.

Dilin temel yapıtaşlarını oluşturan sözcükler, dış dünyanın algılanışını kolaylaştırmanın yanında insanların düşünme yetilerinin de yaratıcısı olmaktadır. İnsanlar bütün düşünme faaliyetlerini kavramlarla, yani dış dünyanın sembolik yansımaları olan sözcüklerle yapmaktadırlar. Sözcük olmadan insanın varlık alanında hiçbir şey yoktur (Yalçın ve Özek, 2006, 130-131).

Sözcükler, insan hayatında olmazsa olmaz olan ve dilin yapısını, imkânlarını, sınırlılıklarını, incelik ve güzelliklerinin ortaya konulmasında önemli işlevler gören temel yapıtaşlarıdır. Bu bakımdan okullarda öğrencilerin eğitimlerinde başarılı olmalarından gerçek hayata hazırlanmalarına kadar her alanda belirleyici olan sözcük dağarcıklarının zenginleştirilmesi büyük önem taşımaktadır.

Öğrencilerin sözcük dağarcıklarının zenginleştirilmesinde başvurulan temel araçlar arasında ders kitapları ve bu kitaplardaki metinler yanında belki de ilk başvuru kaynağı okul sözlükleridir.

\section{Araştırmanın Amacı}

Bu araştırmanın amac1; yapısı, işlevselliği ve hazırlanma ölçütleri bakımından okul sözlükleri ile ilgili genel bir görünüm vermek ve öğrencilerin seviyelerine uygun söz varlığı kazanmalarına katkı verebilecek temel araç işlevi görebilecek ilk, orta ve lise düzeyinde ardışık tematik Türkçe sözlüklerinin hazırlanmasının gereğine işaret etmektir. Bu amaçla okul sözlükleri ile ilgili yapılan literatür taramasıyla ulaşılan bilgiler araştırmanın amacı çerçevesinde ortaya konulmuştur. Ayrıca, ilk, orta ve lise düzeyinde tematik Türkçe sözlüklerinin hazırlanmasıyla ilgili bir modelleme önerisi ortaya konulması amaçlanmıştır.

\section{Yöntem}

$\mathrm{Bu}$ çalışma, nitel araştırma yaklaşımı çerçevesinde literatür taramasına dayalı bir tarama ve derleme çalışmasıdır. Bu çerçevede özellikle lisansüstü tezlerde dile getirilen sorunlar bağlamında eğitim sözlüklerinin biçimsel-içerik özellikleri ile okul sözlüğü hazırlama süreç, ilke ve ölçütleri üzerinde durulmuştur.

\section{Sözlük ve Sözlük Türleri}

Sözlük, bir dilin sözvarlığını, söyleyiş biçimleriyle, yazımlarıyla veren, bağımsız biçimbirimleri temel alarak bunların, başka öğelerle kurdukları söz öğeleriyle birlikte anlamlarını, değişik 
kullanımlarını gösteren sözvarlığı kitabıdır (Aksan, 2007: 75). Sözlük, bir dildeki sözlüksel birimlerin tümünün ya da bir bölümünün tanımlarını, söylenişlerini, kullanımlarını ve dilbilgisel ulamlarını verir. Sözlük, bir dildeki sözcüklerin bütününü belli bir sıra içinde betimler ve onların anlamlarını, değerlerini ve her türlü kullanım özelliklerini belirtir (Günay, 2007: 283-284). Sözlük, dildeki sözcüklerin farkl1 bağlam içerisinde yüklendikleri farklı anlam boyutlarını belli bir sistem içerisinde örneklendirerek veren temel başvuru kitaplarındandır.

Sözlükler yüzyıllar boyunca benzer amaçla kullanılmış olsalar da zaman içerisinde farklı gereksinimleri karşılayabilmek için farklı içerik ya da biçimlerde sözlükler yazılmıştır. Böylece farklı tipolojilerde sözlükler ortaya çıkmıştır. Sözlük türleri şu şekilde sıralanabilir: genel sözlükler, içerdiği dil(ler)e göre (tek-çift-çokdilli) sözlükler, resimli sözlük, pedagojik sözlükler (okul sözlüğü, öğrenci sözlüğü), cep sözlüğü, deyimler sözlüğü, atasözleri sözlüğü, argo sözlüğü, ansiklopedik sözlük, tarihi sözlükler, etimoloji sözlüğü (kökenbilim), sıklık sözlükleri, kafiye sözlükleri, tarama sözlüğü, anlamına göre (eş-karşıt) sözlükler, tersine sözlükler, terim (uzmanlık alanı) sözlükleri gibi (Özcan, 2019). Görüldügü gibi sözlüklerin, yapısı, işlevleri, ait olduğu alan ve kullanacak hedef kitlenin gelişim özellikleri gibi birtakım ölçütlere göre farklı türleri bulunmaktadır.

\section{Sözlüklerin Biçimsel ve İçerik Özellikleri}

Sözlükler, dilde geçen bütün söz varlı̆̆ına yer verilerek onların tanımlarının yapıldığı, okunuşlarının, yazılıșlarının, vurgularının, hangi dilden olduklarının belirtildiği; dil bilgisindeki yerlerinin gösterildiği; uzak ve yakın, gerçek ve mecaz bütün anlamları örnekleriyle ortaya konulduğu dilin temel kitaplarıdır. Hatta birçok sözlük edebî eserlerden seçilmiş olan örnek cümlelere ve ayrıca atasözlerine de yer vererek dili güzel kullanma yolunda k1lavuzluk da yapmaktadır (Böler, 2006).

Çotuksöken (1999: 62-64) de incelediği 20 dolayındaki okul sözlüğüyle ilgili gözlem ve eleştirilerini dile getirdiği çalışmasında "Belki bundan sonra okul sözlüğü yazacak olanlar, benim eleştirdiğim konularda düşünürler ve bugünkülerden çok daha nitelikli sözlükler yazarlar." şeklinde bir giriş ifadesinden sonra sözlüklerin taşıması gereken özellikleri biçim ve içerik yönünden aşağıdaki gibi sıralamıştır:

I-Biçim Yönünden

a.Dizgi-baskı: Okul sözlüklerini öncelikle dizgi-baskı ve ciltleme açısından değerlendirilmelidir.

b. Resimleme: Kimi okul sözlüklerine konulan resimler hangi sözlükbirimlere göre seçilmiştir? Bunda benimsenen ölçüt nedir?

II-İçerik Yönünden

a.Hedef kitle: Hedef kitlenin belirlenmesi, hangi kitleyi amaçladığına öncelikle karar verilmelidir. Öğretim basamakları ya da yaş grupları ölçüt olarak alınabilir.

b.Sözvarlığı: Madde başı sözcüklerin belirlenmesi ayrı bir sorun olarak ortada duruyor. Özellikle türevlerin, kalıp kullanımların (kalıp sözler ve deyimler, ikilemeler vb. hangi ölçüte göre alındığını/alınmadığını açıklayabilmek çok zor görünüyor.

Hedef kitle belirlendikten sonra bu kitlenin gereksinme duyduğu sözvarlığını saptama işi bir ölçüde kolaylaşabilir. Bunun için de öncelikle sıkı bir kaynak taraması yapılıp sözcük listesi hazırlanmalıdır. Bu konuda öncelik o gruba özgü yayınları (ders kitapları, dergiler vd.) tanınabilir.

c.Yazım ve sesletim: Okul sözlüklerinde sözcüklerin sesletim özelliklerinin verilmesi (vurgu, uzunluk, kimi ünsüzlerdeki incelik ve kalınlık) göz ardı ediliyor. Okul sözlüklerinin yazımında TDK'nın imla kılavuzu kullanılmamalıdır. Hemen her bir sözlükbirimin sesletim özelliği okul sözlüklerinde de yalınlaştırılmış biçimleriyle verilmelidir.

d.Kökenbilim: Okul sözlüklerinde kaynak dil, kısaltmalarla (Al., Far., İng. gibi) verilebilir.

e.Sözcük türü: Okul sözlüklerinde sözlükbirimlerin sözcük türü açısından betimlenmesi ve bunun belirli kısaltmalarla gösterilmesi oldukça yararlıdır.

f.Tanımlama: Okul sözlüklerinde sözlükbirimlerini, açık, anlaşılır, tam ve doğru biçimde tanımlanması da önemlidir. Tanımlar, öğrencilerin düzeyinin üstünde ya da anlaşılmaz bir durumda olursa o sözlük sadece işlevsiz olmakla kalmaz, tehlikeli de olabilir. Okul sözlüklerinde tanımlar açık, anlaşılır ve doğru olmalıdır. Uzun tanımlardan olabildiğince kaçınılmalıdır. 
g.Örnek tümceler: Okul sözlüklerinde de gerek görüldükçe tanımlardan sonra örnek kullanımlara da yer verilmektedir.

Karadağ (2011) sözlüklerin içerik/kapsam özelliklerini sıralarken şu hususları vurgulamaktadır:

- Öğrenci başvurusunu karşılaması.

- Sözlükbirimlerin tanımlanması ve açıklanmasında öğrenci seviyesinin dikkate alınması. bulundurulmasi.

- Anlam birimlerinin oluşturulmasında öğrencilerin bellek özelliklerinin göz önünde

- Birden çok anlama sahip sözlükbirimler anlamları verilirken önem sırasının gözetilmesi.

- Madde başları Türkçenin şekil bilgisi özellikleri dikkate alınarak belirlenmesi.

- Yabancı kökenli kelimelerin öncelikle Türkçe karşılıklarının verilmesi, sonra tanım ya da açıklamasının yapılması; Türkçe kelimelerin ise öncelikle tanım ya da açıklamasının yapılması, sonra eş ve zit anlamlarının verilmesi.

- Türkçede sık kullanılan deyim ve atasözlerinin okul sözlüklerinde yer alması.

Sözlükler dışından (kapak), içine (madde) belli bölümlerden oluşurlar. Sözlükler içerdikleri bilgilerin özellikleri ve boyutları bakımından değişiklik göstermektedir. Bundan dolayı sözlük incelemesinde bu farklılıklar göz önünde tutularak her bir birimi farklı alanlara ve alt alanlara ayırarak adlandırılmaktadır. Makroyapı genel olarak tüm referans kaynaklarında, o kaynağın barındırdığı bilgi ya da bilgiler bütününün bulunduğu yapıdır, bu bağlamda mikroyapının da kapsayanıdır. Makroyapının en bilindik örneği, sözlüklerde yer alan alfabetik sözcük listesidir. Bahsedilen liste içerisinde yer alan her bir sözcük madde olarak adlandırılır. Söz konusu liste içerisinde yer alan sözcükler ve bu sözcüklerle ilgili verilen tüm bilgilerin bütünü (madde/maddebaşı/başsözcük, açıklama, tanım, örnek) mikroyapıyı oluşturur (Özcan, 2019: 47-50).

\section{Sözlük Hazırlamada Temel Sorunlar}

Ülkemizde sözlük yazma konusunda hâlâ teknik sorunlar yaşanmakta olduğunu ifade eden Basatemur (2013: 11), Boz’un (2011) bu teknik sorunları aşağıdaki gibi sıraladığını aktarmaktadır:

- Sözlük hazırlamada seçilecek yöntem,

- Amaç ve hedef kitlenin belirlenmesi,

- Madde başlarının belirlenmesi,

- Madde başlarının sıralanması,

- Madde başlarının tanımlanması,

- Madde başları için örnek cümlelerin belirlenmesi,

- Diğer sorunlar.

Genel bir değerlendirme ile sözlüklerin; 'a) Ansiklopedik. Bu gruptaki sözlüklerde durumlar ve olaylar izah edilir. b) Filolojik. Bu gruptaki sözlüklerde ise, sözcükler açıklanır, anlamları yorumlanır.' şeklinde iki türe ayrıldığını açıklayan Usta (2006: 227-239), yaptığı sözlük inceleme çalışmasında tespit ettiği örneklerden hareketle sözlüklerde ortaya çıkabilecek eksikler ve yöntem hatalarını aşağıdaki gibi siralamaktadır:

- Objektif olabilmek ya da benmerkezcilik

- Gündemi izleyebilmek ya da güncellik

- Bask1 öncesi kontrol

- Madde başı, iç madde: yanlış, gereksiz, bozuk/hatalı maddeler, madde içi yetersiz bağlantı, maddeler arası yetersiz bağlantılar

- Yanlış etimoloji tanımlamalar.

- Tanımlama/Açıklama: yanlış, eksik, yetersiz, bozuk, belirsiz, gereksiz açıklama/

- Örneklendirme: yetersiz, gereksiz/yararsı örneklendirmeler.

- Anlam sırası karışık

- Türkçe dil bilgisine aykırılık: Sesbilgisi, anlambilgisi, biçimbilgisi ve sözdizimi açısından. 


\section{Sözlük Hazırlamada Yaklaşım ve Unsurlar}

"Sözlükler hazırlanırken genel olarak iki yaklaşımla hareket edilmektedir. Bunlardan birincisi, sözcükler betimlenirken köken bilimsel ve biçim bilimsel durumlara yer veren yaklaşım. İkincisi ise, ansiklopedik tanımlarla nesnelerin betimlemesi yapıldığı yaklaşımdır. Ülkemizdeki birçok sözlügü̆n bu yaklaşıma göre hazırlandığı söylenebilir (Günay, 2007: 36)".

"Sözlük türlerinde yaş gruplarına ve öğrenim düzeylerine göre hazırlanan sözlükler özel bir yer oluşturmaktadır. Eğitbilimsel olarak da adlandırılan bu sözlüklerin hazırlanışında düzeylere göre madde başlarının ve içlerinin belirlenmesi; anlamların seçilmesi, tanıkların gösterilişi gibi doğrudan doğruya sözlük bilimini ilgilendiren özellikler bulunmaktadır (Akalın, 2017: 865)”.

Bir sözlüğün içeriğine genel olarak bakıldığında aşağıdaki gibi bir görünüm ortaya çıkacaktır (Özcan, 2019: 55):

• Önsöz (ya da Sunuş)

- Kisaltmalar

- Kullanım hakkında notlar/Açıklamalar

- Madde listesi ve tanımlamaları.

Sözlük yazarları hazırladıkları sözlüklerin çeşidine göre parçacıl yapıyı (mikro yapı) şekillendirirler. Sözlüğün hitap ettiği kitleye göre parçacıl yapıda sunulan bilgilerin çeşitliliği de değişebilmektedir. Genel sözlüklerde parçacıl yapıyı oluşturan bilgileri şöyle sıralayabiliriz (Alan, 2017: 628):

- Madde baş1

- Yazım/İmla bilgisi

- Sesletim

- Dilbilgisel bilgi

- Köken bilgisi

- Kullanım etiketi

- Tanım bilgisi

- Örnek

Madde içinde birçok alt öğeyi barındırarak sözcükle ilgili bilginin verildiği yerdir. Sözlüklerin başında sözlüğün nasıl kullanılacağını açıklayan bir rehber bulunmaktadır. Burada sözlükte kullanılan kısaltmalar, şekiller, farklı yazım biçimleri (koyu, eğik, altıçizili vs.) verilerek kullanıcılara, hangi bilgiyi sözlüğün neresinde bulacağı gösterilmektedir (Özcan, 2019: 28-29).

\section{Sözlük Hazırlama Sürecinin Aşamaları}

McGregor gibi Svensén (1993), sözlük oluşturma sürecini iki aşamaya ayırmaktadır (Aktaran Golynskaia, 2017: 35):

1. Planlama:

a) ihtiyaç belirleme,

b) ön planlama,

c) ön analiz,

d) proje planının tekrar gözden geçirilmesi,

e) örnek bir bölüm hazırlama,

f) nihai planın kesinleştirilmesi.

2. Uygulama:

a) materyal toplama ve seçme,

b) taslak oluşturma,

c) metni yeniden gözden geçirme,

d) üretim (düzeltme okuması dâhil).

Sözlük yapım sürecinde büyük ölçekli bilginin küçük bir alana sığdırılması ihtiyacının doğurduğu kullanıcı dostu sözlük hazırlama anlayışına değinen Yılmaz, sözlük hazırlama aşamalarını şu şekilde siralamaktadır (2017a: 13-18):

•Sözlük hazırlayıcılarının belirlenmesi, 
- Hedef kitlenin belirlenmesi,

- Amacin ve zamanın belirlenmesi,

- Yöntemin belirlenmesi,

- Yazıl1/sözlü ürünlerin taranarak derlem havuzunun oluşturulması,

- Sözlüksel birimlerin (madde başı) belirlenmesi,

- Sözlüksel birimlerin (madde başı öge) tanımlanması.

Bir sözcüğün maddebaşı olarak kabul edilip edilmeyeceği, birtakım etkenlere bağlıdır (Golynskaia, 2017: 65):

- Sözcüğün kullanım sıklığ1,

- Hedef kullanıcı kitlesinin ihtiyaçları,

- Sözcügün yan anlamları.

Sayan (2005: 388), okul sözlüklerinde tanımlar üzerine yaptığı bir araştırmasında kavramların tanımlanması ile ilgili şu hususlara dikkat edilmesini istemektedir:

- Tanım, tanımlayan terimin bütününü kapsamalı ve yalnız tanımlanana ait bulunmalıdır.

- Bir kavram kendisinden daha açık olmayan başka bir kavramla tanımlanmamalıdır.

- Kavram kendisine bağlı bir kavramla açıklanmamalıdır. Tanımda kısır döngü olmamalıdır.

Başlıca Sözlüksel Tanımlama Yöntemleri (Yılmaz, 2017b: 205): yapilir.

- Çözümleyici tanım: Tanımlanan kavramın anlambirimcik çözümlemesine dayalı olarak

- Sözcük eşleştirmeye dayalı tanım: Kavram; eş, yakın, karşıt anlamlılarıyla tanımlanma yoluna gidilir.

• Özgüleştirici tanım: Tanımı yapılan kelimenin “tipik” niteliğine, özellikle karakteristik olan anlambirimciğe odaklanılır.

- Birleştirici tanım: Çözümleyici tanımın aksine tanımlanan kavramın ait olduğu küme içindeki diğer ögelerle ilişkisi dikkate alınır.

- Kurala dayalı tanım: Genellikle bir dilin gramerinde, bir sözcüğün veya bir sözcüğün anlamının kullanım bilgisinden hareket edilir. "Dilbilgisel" veya "işlevsel" sözcükler, yansıma sözcükler ve seslenme bildiren sözcükler tanımlanırken genellikle bu yöntemden yararlanılır.

\section{Sözlük Hazırlama İlkeleri}

Aslan Demirtaş, sözlüklerin işlevini tam anlamıyla yerine getirmesini sağlaması bakımından sözlükler hazırlanırken biçim ve içerik özellikleriyle birlikte aşağıda sıralanan temel ilkelere de uyulmasına işaret emektedir (2010: 22-26):

- Amaç ve Hedef Kitleye Uygunluk: Hazırlanacak sözlügün hedeflenen kitleye yararlı olabilecek şekilde sözcük seçimi yapılmalıdır.

- Yöntemin Belirlenmesi: Sözlük çalışmaları, yenilikleri takip etmeyi ve gerektiği zaman eklemeler yaparak üzerinde sürekli durmayı gerektirmektedir.

- Madde Başlarının Belirlenmesi: Amaç ve hedef kitleye uygun olarak madde başlarının belirlenmesinde bilinirlik ve kullanım sıklığı ölçütleri önemli rol oynamaktadır. Ayrıca sözlüklerin bilimsel ve güvenilir özellik taşıması için bazı ölçütlere yer verilmektedir. Bunlar: gerçeklik, sıklıkta tutarlılık, uygunluk, eski-yeni sözcükler, yerel sözcükler, kapsam, genel/teknik sözlükler, sözlü/yazılı dil.

- Tanımların Verilmesi: Sözlükler için tanımların verilmesi en temel işlevdir. Sözlüklerde yer alan madde başlarının tanımlayııı, açıklayıcı, doğrulayıcı, önerici, örneklendirici yönlerinin ağırlıkta olmas1 gerekir.

- Dil ve Gramere Uygunluk.

- Tarihi Kaynaklara Bağl1lık.

Reihard Hartmann'ın, sözlük yapımı için önerdiği şu ilkeler, sözlük hazırlamada göz önünde bulundurulması gereken boyutlara dikkat çekmektedir (Aktaran Çakmak, 2010: 24):

- Sözlükler, bir dilin bütün sözvarlığını ya da bir ila birden fazla alanını betimler.

- Sözlük yapımcılığı, bilgiyi sunmak ve işlemek için bir üstdil geliştirmek durumundadır. 
- Aslında bütün sözlükler, hizmet ettikleri dil kullanıcılarının dilsel ihtiyaçlarına göre biçimlendirilir ve değerlendirilir.

Sözlük hazırlarken üzerinde titizlikle durulacak nokta, sözlükte yer verilecek sözcüklerin seçimi işlemidir. Sözlükte yer verilecek sözcüklerin hedeflenen kitlenin bilişsel (sıralama, sınıflama, sebepsonuç ilişkisi kurma, muhakeme etme, anlam kurma, çıkarımda bulunma, vb.) becerilerin zemin sunmas1; dilsel (anlaman-anlatma) becerilerin etkin kullanımına katkı vermesi gerekir.

Sözlük hazırlamada yöntem ve ilkelere değinen Kahraman (2016: 3301-3302) da şu üç hususun altını çizmektedir:

- Sözlük hazırlamada en büyük güçlük eserde yer verilecek sözcüklerin seçilip belirlenmesidir.

- Bir dilde kullanılan sözcüklerin tümüne yer vermek neredeyse imkânsızdır. Sözlük hazırlarken yapılacak en önemli şey, tanımların verilmesidir.

- Diğer bir nokta, sözlük hazırlama sürecinde amacın ortaya konulmasıdır. Amaç belli bir kitleye hitap etmekse, söz varlığının nicelik ve nitelik açasından ona göre düzenlenmesi gerekir. Anadil sözlüklerinde olduğu gibi iki dilli sözlüklerde de temel sözvarlı̆̆ 1 ve sıklık dizelgeleri göz önünde bulundurulmalidir.

Sözcük türü, sözcüğün cümlesel özelliğiyle alakalı bir durumdur ve bir sözcük, tek başına türünü ifade edemez. Bu nedenle, sözlüklerde sözcüğün türünün gösterilmemesi daha uygundur. Sözlüklerde yapıbilimsellikten ziyade anlambilimsellik ön plana çıkarılmalı, bu konuya kişisel tercihlerle değil, sözlükbilimsel bir çerçevede yaklaşılmalıdır (Armağan, 2017: 745-746).

\section{Okul Sözlükleri}

Türkiye'de sözlükçülük ile ilgili bir kurumlaşama sağlanamadığı için sözlük yazmayla ilgili sorunlar bir türlü tam olarak çözümlenememektedir. Özellikle Latin abecesine (1928) geçildikten sonra pek çok sözlük yayımlanmıştır: genel Türkçe sözlükler, terim sözlükleri, atasözleri ve deyimler sözlüğü, anlamdaş ve karşıtanlamlılar sözlüğü, derleme, tarama, uyak, okul sözlükleri... Bu sözlüklerin tümünün nitelikli, işe yarar, işlevsel olduklarını söylemek pek olanaklı değildir. Özellikle okul sözlükleri söz konusu olduğunda eleştiriler daha da yoğunlaşmaktadır (Çotuksöken, 1999: 61).

Okul çocukları için yazılan, genel özellikleriyle bir tanım sözlüğü olan, sade bir tasarım ve resimlerle desteklenen sözlükler, okul sözlüğü olarak adlandırılır (Akalın, 2017: 871). Okul sözlüğü kavramı, öğrenciler için hazırlanan bazı sözlükler için kullanılmasına rağmen teorik içeriği belirgin değildir. Ülkemiz yazınında okul sözlükleri üzerine yapılan çalışmaların sınırlı sayıda olduğu ve akademisyenler tarafindan yapılan sözlük sınıflandırmalarında okul sözlüklerine yer verilmediği görülmektedir (Aslan Demirtaş, 2010: 35). Günümüzde gerek iki dilli gerekse Türkçe sözlükler oldukça fazladır. Ancak bunların tümünün nitelikli, işlevsel olduğu söylenemez. Okul sözlükleri üzerinde yeterli bir çalışma yapılmamışırı. Tam olarak kaynakçası bile bilinmemektedir. Bunlar üzerinde yeterli bir denetim olmadığı için ciddiyetten yoksun oldukları görünmektedir (Kaya, 2007: 33).

Günümüzde hazırlanan sözlükler zaman içinde edinilen deneyim ve ilerlemeler çerçevesinde bir takım ölçütlere göre oluşturulmaktadır. Ölçütlerin belirlenmesinde sözlüğün amacı ve hangi hedef kitleye hazırlandığı önemlidir. Belli seviyelerdeki öğrenci sözlükleri, dilin temel sözvarlığını sunan kapsamlı genel sözlüklerle bir tutulamaz (Elyıldırım, 2017: 752). Bu açıdan okullarda öğrencilerin kullanmaları amacıyla hazırlanacak sözlüklerin, genel olarak hedef kitlenin özellikleri göz önünde bulundurularak hazırlanması gerekmektedir. Usta'ya (2006: 240) göre, sözlüğü hazırlamada hangi yöntemin kullanılacağı belirlendikten sonra, ne tür sözlükler yazılacağına, bunların hedef kitlesinin kimler olacağına uzmanların da görüşü alınarak ihtiyaca göre karar verilmelidir.

Yabancı dil sözlüklerinin düzenleniş ve içerik açısından anadili sözlüklerinden daha yöntemli ve dizgeli hazırlanmış, derlem ve geri bildirim verileriyle güncellenerek öğretim ortamları için daha işlevsel oldukları söylenebilir. Sözlük kullanma alışkanlığının gelişebilmesi için, sözlüğün, dil kullanım özelliğinin ve görselliğinin iyi olması gerekir. Ayrıca, derlediği bilgilerin güncel, sunuş biçiminin düzenli ve tahmin edilebilir olması da önemlidir. Türkçe sözlükleri ve okul sözlükleri içeriksel ve sunumsal eksikliklerine eleştirel bir bakışla değinen birçok çalışma vardır (İbe Akcan, 2015). 
Okul sözlüklerindeki (önemli) bir sorun, bu sözlüklerin genel sözlüklerden küçültme/kısaltma yoluyla hazırlanmasıdır. Sözlüğü hazırlayan kişi tamamen kendi öngörüsüyle sözlüğe bazı maddeleri almakta, uygun olmadığını düşündüğü maddeleri dışarıda bırakmaktadır. Sözlüğe alınan maddelerin ilk birkaç anlamı verilmekte, örnek kullanımlar çoğunlukla dışarıda bırakılmaktadır (Karadağ, 2011).

Usta (2010), sözlükçülük teorisinin genel olarak iki başlıkta incelendiğini aktarmaktadır. Bunlar: Teorik sözlükçülük: Sözlügün makro-yapı (sözcük dizininin hacmi, niteliği ve sözlüğe yerleştirme ilkeleri) ve mikro-yapı (madde başının yapısı, dil bilgisi örneklerinin türü vb.) hazırlı̆̆ yanında sözlük tipolojisinin kurulması ve sözlükçülük tarihi ile ilgili problemleri kapsamaktadır. Pratik sözlükçülük: Dil öğretimini, dili tanımlamayı ve standartlaştırmayı, dilin bilimsel incelemesini yapmakla çok önemli toplumsal bir fonksiyonu yerine getirmektedir (s. 96).

Tasnife bakıldığında sözlüğün ne'liği/ne olduğu, yapısı, bu açıdan araştırmanın odağında olması veya 'amaç' olarak görülmesi teorik sözlükçülük ile ilgili olduğu söylenebilir. Araştırma ve inceleme mahsulü tarama ve derleme sözlükleri, dil bilgisi terimleri sözlüğü... bu grupta ele alınabilir. Pratik sözlükçülükte ise; sözlüğün nasıl'lığı/uygulamadaki kullanımı, yapısından çok işlevi, bu açıdan öğrenmenin ve eğitimin odağında olması veya 'araç' olarak görülmesinden söz edilebilir. Okul sözlükleri bu grubun en önemli örnekleridir.

Dil becerilerinin gelişimi insanın kelime dağarcığı ile yakından ilgilidir. Öğrencinin kelime haznesi ne kadar geniş olursa okuduğunu o derece iyi anlar ve kendini yazarak-konuşarak o derece iyi ifade eder. Bunun sağlanmasında en temel araçlar ders metinleri ile Türkçe sözlükleridir. Sözlüklerle hedeflenen amaçlarının gerçekleşebilmesi için yapılması gereken en önemli husus sözlüklerin söz varlığının öğrencilerin hedef söz varlığı ile uyumlu hale getirilmesidir. Bu da ancak sinıf sözlüklerinin hazırlanması anlamına gelir. Zira her bir sınıf düzeyinde öğretilecek kelime listeleri ve sözlüksel unsurları farklıdır. Sınıf seviyesine uygun sözlük hazırlamak yapılandırmacı yaklaşımın da bir gereğidir (Aksoy, 2018: 1-2). Sinıf düzeylerine uygun sözlük hazırlanmasının avantajlarından söz edilse de gerçekleştirilebilirliği, kullanılabilirliği ve genel olarak eğitsel yararları açısından öncelik sıralamasında sınıf sözlükleri yerine ilkokul, ortaokul ve lise olarak belirlenmiş eğitim sürecinin temel kademelerine yönelik okul sözlükleri hazırlanması pratik açıdan daha mantıklı görünmektedir.

\section{Okul Sözlüklerinin İşlevleri ve Eğitsel Değeri}

Türkçe eğitiminin temel araçlarından biri okul sözlükleridir. Sözlük, özellikle anlama becerilerinin kullanılmasında önemli bir eğitim ortamı oluşturur ve anlatma becerilerinin sergilenmesinde, iletilecek anlamın, yazımın ve söyleyişin doğrulanması bakımından öğrenciye rehberlik eder (Karadağ, 2011: 195).

Temel bir başvuru kitabı işlevini taşıyan sözlüklerin, dil eğitiminde işlevsel kullanılabilmesi ve pedagojik bir değer taşıması için hedef kitlenin özellikleri dikkate alınarak hazırlanmış olması gerekir. İlk, orta ve lise öğrencilerinin kullanması için hazırlanacak sözlüklerin eğitsel amaçlar doğrultusunda öğrenmeye aracılık etmesi için hedef kitlenin özellikleri, öğrenim görülen eğitim düzeyinin kazanımları vb. değişkenlerin dikkate alınarak ve kapsamı daraltılarak çerçevesi çizilmiş olması pedagojik bir zorunluluktur.

Sözlük hazırlayıcılarının eserlerini oluşturmaya başlamadan önce hedef kitlelerini ve bu hedef kitlenin sözlük ihtiyacını belirlemekle işe başlamalarının gereğine işaret eden Baskın (2017: 778), Boz'dan (2006), "Hedef kitlenin beklentilerine cevap veremeyen sözlüklerin başarılı olma ihtimali yoktur." sözünü aktarmakta ve şöyle devam etmektedir. Türkiye'deki okul sözlükleri incelendiğinde bu tür analize dayanmadıkları, daha çok sezgisel bir temele dayanırlar ve yazarlarının öngörüsüne göre şekillendikleri görülür (s. 779).

Okul sözlüğü hazırlamasının en güç yanı sınırlı bir hacim içinde öğrenci ihtiyaçlarının karşılanmasıdır. Temel eğitim çağındaki öğrencilerin ihtiyaçlarını en ideal biçimde karşılayacak, öğrencilerin ilgisini çekecek ve onların söz varlığını geliştirmeye yardımcı olacak sözlüklerin hazırlanması büyük önem taşımaktadır. Sözlük hazırlamada en temel nokta, sözlük hazırlama amacının belirlenmesi ve bu amaç doğrultusunda hedef kitlenin özelliklerinden hareket edilmesidir (Karadağ, 2017: 157). 
Dil eğitimi ve öğrenimi süreçlerinde sözlükler temel başvuru kaynağıdır ancak sözcük öğretimi etkinliklerinde ilk yapılacak iş sözlüklere bakmak/baktırmak olmamalıdır. İlkokulun ilk sınıflarında öğrenciler metinlerde ilk kez karşılaştıkları sözcükleri öğretmenin yardımıyla doğrudan sözlüğe başvurarak öğrenmesi yoluna gidilebilir. Ancak, okulda sınıf düzeyi yükseldikçe sözcük öğretiminde doğrudan sözlüğe bakma girişimi azalmalıdır. Çünkü her sözcük bulunduğu bağlama göre değişik anlamlarda kullanılmaktadır.

Öğrencilerin sözcük çalışmalarıyla kalıcı ve kullanılabilir öğrenme gerçekleştirebilmesi için söz ya da yazıda ilk kez karşılaştığı sözcükleri sözlüğe bakmadan önce bilişsel stratejiler kullanarak öğrenmesinin süreçleri işletilmelidir. Bu çerçevede ilk kez karşılaşılan sözcüğün anlamını sözün gelişinden tahmin etme veya anlamını bağlamdan çıkarma girişimlerinin yapılması gerekir. Bunun için ipuçları verme, değişik sözcüklerle farklı cümlelerde kullanma, sözcüğün eş, zıt ve yakın anlamlarında kullanma gibi aşamalarla öğrencinin olası anlamı çıkarması sağlanmalıdır. Bütün çabalara rağmen sözcüğün anlamı tahmin edilip bulunamıyorsa sözlüğe baktırılmalı ve sözlükteki hangi anlamı metin ya da bağlamdaki anlam olduğu yine öğrenciye buldurulmalıdır.

Kişinin yaşamında önemli bir yer tutan sözcük dağarcığına sahip olunması okullarda gerçekleştirilen dil eğitimde sözlük bilgisi ve sözcük öğretimini gündeme getirmektedir. Eğitim süreçlerinde öğrencilerce sözcük öğreniminin öneminin kavranması, sözcük öğrenme ile ilgili çalışmalarda sözlüğe başvurmanın üzerinde durulması gereklidir (Göçer, 2016: 377).

\section{Okul Sözlükleri İçin Bir Model Önerisi: Tematik Okul Sözlükleri}

Mustafa Nihat ÖZÖN okul sözlüklerinin ilki olan Türkçe okul sözlüğünü 1945’te yayımlamıştır (Aktaran Yılmaz ve Koçmar, 2009: 85). Daha sonraları; Örneklerle Türkçe Okul Sözlügüü (Ali Ertan, Ak Kitabevi, İstanbul 1964), Ortaokullar İçin Türkçe Sözlük (Emek İş Yayınevi: İstanbul 1972), İlkokullar İçin Türkçe Sözlük (Özgül Yayınları, Isparta 1985)... (Kaya, 2007: 35) gibi okul sözlükleri hazırlanmıştır. O yıllarda okul sözlüğü adıyla belli bir hedef kitle düşünülerek ve belli bir sınırlandırma yapılarak bu tür sözlüklerin hazırlanması; amaç, hedef kitle ve kelime kadrosu bakımından tematik bir yaklaşımla hareket edildiğini göstermektedir.

Okul sözlükleri hazırlanırken dil eğitiminde belirlenen amaçların gerçekleştirilmesi göz önünde bulundurulmaktadır. Okul sözlüklerinin hazırlanmasında, öğrencilerin Türkçeyi daha iyi öğrenerek günlük hayatında doğru kullanması temel amaçtır. Öğrencilerin yardımcı kaynaklara başvurması alışkanlığının alt yapısını oluşturmak. Bilmediği bir şeyi nereden ve nasıl öğreneceğini (kaynak eser kullanımını) öğrenen öğrencinin problem çözme yeteneği de gelişecektir. Özellikle ilköğretimin ilk yıllarında öğrencilerin sözlük kullanmayı öğrenerek kendi başına iş yapabilme becerisini geliştirecek ve daha başka işler başarabileceği özgüvenini oluşturacaktır. Sözlük kullanma, Türkçenin doğru öğrenilmesini ve öğrenilenlerin yerinde kullanımına yardım eder (Göçer, 2001: 400).

Farklı seviyeler için hazırlanan sözlüklerde, sözlerin karşılıkları verilirken ilgili yaş düzeyinin algılama seviyesi dikkate alınmalıdır. Kavramların tanımlanması ve örneklendirilmesinde, öğrencilerin kullanabileceği cümle uzunluklarına uygun olarak hareket edilmesi gerekir. Yapılan açıklamaların da öğrencilerin sahip olabileceği söz varlığına uygun olması sözlüğün işlevselliğini arttıracaktır. Öğrencilerin anlama ve anlatım özelliklerinin bilinmesi ve anlam birimlerinin buna göre oluşturulması önemlidir (Karadağ, 2011). Kısaca ifade etmek gerekirse okul sözlükleri hazırlanırken ait olduğu eğitim kademesinde öğrenim gören öğrencilerin dilsel, bilişsel, duyuşsal ve psikolojik özelliklerine göre biçimsel ve içerik açılarından uygun olmasına dikkat edilmesi büyük önem taşımaktadır.

Günümüzün kuramsal sözlükbiliminde hüküm süren kullanıcı görünümü, sözlükbilimcileri sözlüklerini iyi tanımlanmış hedef kullanıcı gruplarının ihtiyaçlarına ve bilgi edinme becerilerine göre derlemeyi teşvik etmektedir. Kullanıcılar, derlenmesinde olduğu kadar sözlüklerin değerlendirilmesinde de başat bir rol oynamaktadır (Golynskaia, 2017: 38).

Okul sözlükleri hazırlanırken sınıf düzeyi ve öğrencilerin belirlenmiş yaş gruplarına göre (sorulan sorulara verdikleri cevaplardan, ders kitaplarının kelime kadrosundan, yazma etkinlikleriyle oluşturulan metinlerden, hazırlıkl1-hazırlıksız konuşmalardan vb. diğer çalışmalardan) sahip olunan/olunması gereken ortalama kelime kadrosunu içeren kelime havuzları oluşturulmalıdır. 
Oluşturulan kelime havuzları temel alınarak her bir kademedeki sınıf düzeylerini de içine alan okul sözlükleri hazırlanabilir.

Halil İbrahim Usta sözlük hazırlama süreci ve aşamaları ile ilgili olarak 'Türkçe Sözlük Hazırlamada Yöntem Sorunları' başlıklı çalışmasının 'İlkeler' başlığı altında şu bilgileri aktarmaktadır (2006: 226): Sözlükbilimine göre öncelikle,

- amaç belirlenmeli,

- amaca ulaşmak için kullanılacak "dil malzemesi”nin sınırları çizilmeli,

• bu malzemenin derleneceği "kaynaklar" tespit edilmeli,

- bu kaynakları inceleyip tarayarak sözlük hazırlayacak olan sözlükbilimciler (fakat asla yalnızca dilci ve/veya edebiyatçılar değil) bir araya getirilmelidir.

Usta'ya (2006) göre;

• ‘amaç' sözlüğün türünü belirler,

- 'malzeme' sözlügün hacmini/içeriğini belirler,

- 'kaynaklar' sözlüğün hangi zaman dilimine ait olacağını belirler,

- ‘ekip' sözlüğün kalıcı, yararlı ve eksiksiz olmasını belirler.

Ancak yukarıda çizilen bu yolun yanında bazı kaynaklarda farklı bir sıra izlendiği de görülmektedir.

1) Ekip hazırlanmalı.

2) Ekip özel olarak eğitilmeli.

3) Her türden yayını takip etmeleri için fırsat, zaman, imkân ve mekân temin edilmeli.

4) Ekip bir kartotek/korpus hazırlamalı (s. 226)'.

$\mathrm{Bu}$ ilkeler 1şığında şöyle bir yol haritası belirlenebilir:

\section{Amaç}

Sözlük çeşitleri ihtiyaca ve amaca göre sınıflandırılabilmektedir. Sözlüğün hazırlanış amacı belirlendikten sonraki bir aşama ise hazırlanacak olan sözlüğün ilke ve prensiplerini ortaya koyabilmektir (Armağan, 2017: 736). Sözlüğün hazırlanış amacı ilk, orta ve lise düzeyinde eğitim gören ögrencilerin anlama ve anlatma temel beceri alanlarında yeterliklerini doğrudan etkileyen kelime hazinelerinin bulundukları sınıf düzeyinin gerektirdiği zenginliğe ulaşmalarında araç işlevi görmesidir.

Amaç; ilk, orta, lise düzeyinde tematik sözlük hazırlamak. Tematik sözlüklerinin hazırlanmasında yapılması gereken en önemli iş, sözlükte yer verilecek kelime kadrosunu belirlemektir. Farklı eğitim kademelerinde Türkçe ve Edebiyat dersleri çerçevesinde ders kitabı hazırlayıcılar için oluşturulan tema/ünite başlıkları, bu başlıklar altında işlenecek konular bağlamında derlem tabanlı çalışmayla elde edilen kelime kadrosunun yer aldığ ilk, orta, lise kademelerinde kullanılması amacıyla tematik sözlük hazırlanabilir. Alfabe sırasına göre mi, tema/ünite veya konuya göre mi hazırlanacağına kademelerin genel özellikleri ve öğrenci gelişim özellikleri göz önünde bulundurularak metot belirlenebilir. Hazırlanacak tematik sözlüklerde her tema veya üniteyle ilgili yer verilen kelime kadrosuna ek olarak o tema veya ünitenin içeriğine uygun ikileme, kalıp söz, deyim ve atasözlerine de yer verilebilir.

Tematik sözlük hazırlamanın en önemli yararı, hedef kitlenin özelliklerinin dikkate alınarak her eğitim kademesine özgü sınırlandırılmış çerçevede belirlenen kelimelerin yazımının, söylenişinin, tanımının, temel anlamının verilmesi yanında yan, mecaz anlamlarını ve bu anlamların kullanımlarının örneklendirilmesine daha geniş bir zemin sunmasıdır.

Sözlük türleri arasında hazırlanış bakımından tam bir yöntem birliğinin olmadı̆̆ 1 tematik sözlükler, belirli bir konu veya temayla ilgili sözcüklerin madde başı ve alt madde başı şeklinde verilerek tanımlanmasıyla oluşturulmaktadır. Türkçe sözlük çalışmaları açısından henüz yeterince üzerinde durulmamış bu sahada özellikle temel konular veya konu başlıklarının belirlenmesindeki farklılıklar, bu çalışma alanını güçleştiren sebeplerdendir (Mutlu, 2009: 815). Ders kitaplarının kullanımına belli sürelerle izin verilmesi ve belli periyotlarda değiştirilmesi, günümüz dünyasında görülen çok hızlı 
değişme ve gelişmeler sebebiyle eğitim kademeleri için hazırlanan sözlüklerin de belli periyotlarda güncellenip değiştirilmesi gerekmektedir.

Bir dilin söz varlığının farklı tematik sözlüklerde, farklı madde veya konu başlıklarında yer alması, bu sözlüklerin kullanışlılığı açısından sıkıntılara yol açabilmektedir. Araştırmamız sırasında Türkiye Türkçesinin yazı diline ait geniş kapsamlı müstakil bir tematik sözlük çalışmasına ulaşılamamıştır (Türk diliyle ilgili tematik sözlük çalışmalarından ilki, Bahşayiş Lügati'dir. s. 818). Bu nedenle Türkiye Türkçesine ait geniş kapsamlı bir tematik sözlük hazırlanması gerekmektedir (Mutlu, 2009: 821).

Tematik sözlükler eğitim kademelerinde sinıf düzeylerine göre belirlenen her bir tema tema/ünite ve konular baz alınarak anlama ve anlatımda kullanım sıklığına göre okul sözlüklerinde yer verilebilir. Ayrıca, sınıf düzeyleri göz önünde bulundurularak eğitim kademeleri için belirlenen kelime kadrosu ile tema/ünite ve konularla ilgili deyim, atasözü, ikilemeler, kalıp sözler kalıplaşmış dil birimleri başlığı altında sözlük sonunda ayrı bir bölümde kategorik olarak verilebilir. Gökdayı’ya (2017: 389) göre, kalıplaşmış dil birimlerini oluşturan atasözü, deyim, ikileme, birleşik ve kalıp sözler, dil kullanıcılarına hazır kalıplar sunmakta, insanların duygu ve düşüncelerini kolayca iletmelerini ve iletilen mesajları çabucak anlamalarını sağlamaktadır. Bundan dolayı, kalıplaşmış birimlere sözlüklerde önem verilmelidir.

\section{Dil Malzemesi}

Amaca ulaşmak için kullanılacak 'dil malzemesi’nin sınırlarının çizilmesi: Düzeylere göre sözlüklerde yer verilecek kelimelerin kullanım sıklığına göre belirlenmesi.

Bir sözlüğün öğretim aracı olarak kullanılabilmesi ve pedagojik açıdan amaca hizmet edecek işlevselliğe sahip olabilmesi için çerçevesinin iyi belirlenmesi ve içeriğinin iyi düzenlenmesi gerekir. Nation'ın (1990), bir sözcüğü bilmenin neleri gerektirdiği ile ilgili aşağıda sıraladığı yeterlikler bir sözlüğün içeriğinin düzenlenmesinde ölçütler olarak ele alınabilir. Dolayısıyla bu yeterlikler aynı zamanda hazırlanacak sözlüğün içeriğinin belirlenmesine de sşık tutabilir.

Nation (1990), bir bireyin herhangi bir sözcüğü bilmesi için hangi yeterlikleri edinmiş olmas1 gerektiğini veya bir sözcüğü bilmenin neleri gerektirdiği ile ilgili şunları sıralamıştır (Aktaran Yelbay, 2015: 353):

- O sözcüğün anlamını/anlamlarını bilmek,

- Yazılı biçimini bilmek,

- Söyleyișini bilmek,

- Dilbilgisel davranışını bilmek,

- Eşdizimlikleri bilmek,

- Onu belirli bir amaçla belirli bir sosyal ortama uygun kullanabilmek, yan anlamları ve çağrışımlarını bilmek,

- Kullanım sıklığını bilmek.

\section{Kaynaklar} tespiti:

$\mathrm{Bu}$ malzemenin (kullanım sıklığına göre belirlenen kelimelerin) derleneceği 'kaynaklar'ın

Baz alınan eğitim kademesinde (ilk, orta, lise) TTKB onaylı ders kitaplarının ve MEB tarafından eğitim kademelerine özgü destekleyici işlevi bulunan 100 temel eserin taranması ve bu yolla sözlükte yer verilecek kelimelerin belirlenmesi.

Her eğitim kademesi için hazırlanacak tematik okul sözlükleri her kademe içinde yer alan sınıf düzeyleri için hazırlanan ve okullarda okutulması için TTKB tarafindan onaylanan ders kitapları taranarak ilgili eğitim kademesi için hazırlanacak tematik okul sözlüğünün söz varlığı oluşturulmalıdır. Yani ders kitaplarında yer alan sözcüklerin ilgili sınıf (/eğitim kademesi) için hazırlanan sözlüklerde bulunması sağlanmalıdır (Göçer, 2001: 401).

Burada şu soru sorulabilir: Sözlükte yer verilecek kelimelerin belirlenmesinde, her kademe ve o kademedeki sınıf seviyeleri için -sıklık çalışmaları vb. yollarla- kelime havuzları oluşturulup 
belirlenen kelimelerin işlendiği metinler mi oluşturulmalı yoksa her sınıf için hazırlanan ders kitapları taranarak $\mathrm{m} 1$ belirlenmelidir?

\section{Ekip}

Bu kaynakları kullanarak sözlüğü hazırlayacak olan sözlükbilimcilerin bir araya getirilmesi.

\section{Sonuç ve Öneriler}

Okul sözlükleri hazırlanırken kapsam sınırlaması çerçevesinde ve sözlüğün hitap ettiği eğitim kademesinde öğrenim gören öğrencilerin gelişim özellikleri göz önünde bulundurularak, kademeler için aşağıdaki adlandırmalarda örneklendiği gibi her eğitim kademesine özgü ardışık tematik sözlüklerin hazırlanmas1 eğitsel bir zorunluluktur. Burada 'tematik' sözü ile kastedilen sadece Türkçe ders kitaplarındaki temalar kapsamında oluşturulan bir çerçeve değil, sözlük sonunda ilgili kademedeki sınıf düzeylerinin gerektirdiği deyim, atasözü, ikilemeler, kalıp sözler vb. dil birliklerinin de yer verildiği bir çerçeve olarak düşünülebilir.

\section{Illkokul Öğrencileri Iç̧in Tematik Türkçe Sözlük (Basıll) \\ Ortaokul Öğrencileri İçin Tematik Türkçe Sözlük (Basıll + Elektronik) \\ Lise Öğrencileri İçin Tematik Türkçe Sözlük (Elektronik) veya \\ Tematik Türkçe Sözlük: Illkokul Düzeyi (Basilı) \\ Tematik Türkçe Sözlük: Ortaokul Düzeyi (Basılı + Elektronik) \\ Tematik Türkçe Sözlük: Lise Düzeyi (Elektronik)}

Sözlüklerde yer verilecek sözcüklerin belirlenmesinde sözlüğ̈̈n hitap ettiği eğitim kademesinde anlama ve anlatma becerilerine temel teşkil edecek işlek kelimeler olması ve ilgili kademedeki sınıf düzeylerinde kullanılan Türkçe ders kitaplarının kelime kadrosu yanında, mümkün olduğu kadar çocuk ve gençlik edebiyatı ürünlerinin içerdiği de söz varlığının da dikkate alınması önemlidir.

Hazırlanan sözlüklerin yerinde, işlevsel ve pratik kullanımı için basılı şeklinin yanında mutlaka elektronik versiyonunun da hazırlanması gerekir. Cep telefonlarının öğretmenin kontrolünde bir öğrenme aracı olarak kullanılabilmesinin mümkün olduğu günümüzde e-sözlüklerin hazırlanması ihmal edilmemelidir.

Öğrencilerin aktif sözcük dağarcıklarının gelişmesinde inceleme ve çözümlemeye dayalı metin işleme süreçleri içerisinde ve bağlam temelli öğrenme anlayışıyla hareket edilmelidir. Sözcük öğrenimi etkinlikleri sırasında ilk kez karşılaşılan sözcüklerin anlamlarının kavratılmasında sürecin gerektirdiği tüm girişimler yapıldıktan sonra hâlâ anlam çıkarımı yapılamamışsa son aşama olarak seviyeye uygun hazırlanmış eğitim sözlüğüne başvurma olmalıdır.

Zihinlerde yapılandırılması ve işlevsel olarak kullanılabilmesi için sözlüklerde yer verilen sözcüklerin anlamları ait olduğu eğitim kademelerine göre ve mümkünse bir bağlam içinde kullanımı örneklendirilerek verilmelidir.

Sözlüklerde yer verilen sözcüklerin türünü belirten dilbilgisel tanımlayıcıların kullanılmaması daha uygundur. Çünkü sözcükler, kullanıldığı bağlam içerisinde farklı görevlerde kullanılabilmektedir.

Sözlüklerde yer bulan ve birden fazla anlama sahip sözcüklerin anlamları sıralanırken temel anlamdan başlayarak yan, mecaz anlamlarının kullanım özellikleri dikkate alınarak verilmelidir. Türkçe kelimelerin tanım, örnek vb. verildikten sonra eş ve zit anlamlarının verilmesinin eğitsel değeri düşünülmelidir.

Dili kullanım sürecinde sözcüğün cümledeki bulunma görevi farklılık gösterebilmekte, farklı anlam ve işlevlerde kullanılabilmektedir. Yani sözcükler birlikte kullanıldığı kelimelerle farklı anlam yükü yüklenebilmektedir. Bunun sonucunda okul sözlüklerinde yer bulan sözcüklerin sözcük türünün belirtilmesi veya belirli kısaltmalarla gösterilip gösterilmemesi öğrenmenin kalıcılığı ve işlevselliği açısından önemlidir. Bu açıdan yapının mı, kullanım-anlamın mı; şeklin mi, işlevin mi önceleneceğine iyi karar verilmelidir. Karademir'e (2019: 743) göre, söz varlı̆̆ı incelemelerinde suretten manaya geçmeli, sözün mana ve işlevine odaklanılmalıdır. 
Deyim, atasözü, ikilemeler, kalıp sözler, sözlükteki sözcükler arasında değil, sözlük sonunda ve kalıplaşmış dil birimleri başıl̆ğı altında ayrı bir bölümde kategorik olarak verilmesi daha eğitsel ve işlevsel olduğu üzerinde durulmalıdır.

Sözcük öğretiminde bağlam temelli ve işlevsel bir uygulamanın yerleşmesi için öğretmenlere sözlük kullanımı ve sözcük öğretimi çerçevesinde bilinçlendirme eğitimi verilmeli; öğretmen adaylarına lisans eğitimleri sırasında Sözlük Bilgisi ve Sözcük Öğretimi dersi okutulmalıdır. 


\section{Kaynakça}

Akalın, Ş. H. (2017). Okul öncesi ve okul çağı sözlükleri ile ilgili terimler ve sözlük türleri üzerine (ss. 864-873), III. Uluslararası Sözlükbilimi Sempozyumu Bildiri Kitabı (Ed. E. Boz vd.). Eskişehir: Osmangazi Üniversitesi Basımevi.

Aksan, D. (2007). Her yönüyle dil, ana çizgileriyle dilbilim (3. Cilt, 4. Bask1).) Ankara: Türk Dil Kurumu Yayınları.

Aksoy, E. (2018). 5. Sinıf öğrencilerinin hedef söz varlı̆̆ı ve türkçe sözlüğü (Yayımlanmamış Yüksek Lisans Tezi). Tokat: Gaziosmanpaşa Üniversitesi Eğitim Bilimleri Enstitüsü.

Alan, N. (2017). Genel türkçe sözlüklerde eylemlerin tanım bilgisinde verilen dilbilgisel bilgiler (ss. 626-635), III. Uluslararast Sözlükbilimi Sempozyumu Bildiri Kitabı (Ed. E. Boz vd.). Eskişehir: Osmangazi Üniversitesi Basımevi,.

Armağan, S. (2017). Sözcük türlerinin sözlük bilimiyle ilişkisi, sözlüklerde sözcük türlerinin yeri ve önemi (ss. 732-747), III. Uluslararası Sözlükbilimi Sempozyumu Bildiri Kitabı (Ed. E. Boz vd.). Eskişehir: Osmangazi Üniversitesi Basımevi.

Aslan Demirtaş, A. (2010). Türkçe öğretmenlerinin okul sözlüğü kullanma konusundaki tutum ve davranışları (Yayımlanmamış Yüksek Lisans Tezi). Afyonkarahisar: Afyon Kocatepe Üniversitesi Sosyal Bilimler Enstitüsü.

Basatemur, A. (2013). Sözlükbirimlerin tanımlanması bağlamında türkçe sözlüklerin karşılaştırılması (Yayımlanmamış Yüksek Lisans Tezi). Eskişehir: Osmangazi Üniversitesi Sosyal Bilimler Enstitüsü.

Baskın, S. (2017). 5. Sınıf öğrencilerinin sözlük ihtiyacı ve ortaokul sözlükleri. Türkiye Sosyal Araştırmalar Dergisi, 21(3), 765-789.

Böler, T. (2006). Türkçe sözlük (TDK) ile örnekleriyle Türkçe sözlük'ü (Meb) karşılaştırma denemesi. Sosyal Bilimler Dergisi, 1, 101-118.

Çakmak, A. (2010). Sözlük aktarımı üzerine betimleyici ve eleştirel bir çalışma (Yayımlanmamış Yüksek Lisans Tezi). İstanbul: Yıldız Teknik Üniversitesi Sosyal Bilimler Enstitüsü.

Çotuksöken, Y. (1999). Okul sözlükleri üzerine. Kebikeç, 7-8, 61-65.

Elyıldırım, S. (2017). Sözlük maddelerinin düzenlenişi: çokanlamlılık karmaşası (ss. 748-760), III. Uluslararası Sözlükbilimi Sempozyumu Bildiri Kitabı (Ed. E. Boz vd.). Eskişehir: Osmangazi Üniversitesi Basımevi.

Golynskaia, A. (2017). Yabancı dil olarak türkçe öğretiminde tek dilli öğrenici sözlüğ̈̈: model, yöntem ve ilkeler (Yayımlanmamış Yüksek Lisans Tezi). İstanbul: İstanbul Üniversitesi Sosyal Bilimler Enstitüsü.

Göçer, A. (2001). Türk dili ile ilgili sözlüklere genel bir bakış ve günümüz ilköğretim sözlükleri. Türk Dili, 598, 388-403.

Göçer, A. (2009). Türkçe eğitiminde öğrencilerin söz varlığını geliştirme etkinlikleri ve sözlük kullanımı. Turkish Studies, 4(4), 1025-1055.

Göçer, A. (2016). Türkçe öğretmenleri ve öğretmen adaylarının 'sözlük bilgisi ve sözcük öğretimi’ne yönelik yeterlikleri. Millî Ĕ̈itim, 210, 373-390.

Gökday1, H. (2017). Sözlükler ve kalıplaşmış dil birimleri (ss. 381-397), III. Uluslararası Sözlükbilimi Sempozyumu Bildiri Kitabı (Ed. E. Boz vd.). Eskişehir: Osmangazi Üniversitesi Basımevi.

Günay, V. D. (2007). Sözcükbilime giriş. İstanbul: Multilingual Yayınları.

İbe Akcan, P. (2015). Üniversite düzeyinde dil öğrencilerinin sözlük kullanımı. Hacettepe Üniversitesi Edebiyat Fakültesi Dergisi, 32(2), 87-102.

Kahraman, M. (2016). Sözlük bilim kuram, ilke ve yöntemler üzerine. İnsan ve Toplum Bilimleri Araştırmaları Dergisi, 5(8), 3288-3312.

Karadağ, Ö. (2011). İlköğretim türkçe sözlüklerinin hazırlanmasında temel ölçütler. Türklük Bilimi Araştırmaları, 30, 193-207.

Karadağ, Ö. (2017). Okul sözlükleri (ss. 151-158), Ana Dili Olarak Türkçenin Eğitimi ve Öğretimi Çalışma Toplantısı Bildirileri Kitabı. Ankara: Türk Dil Kurumu Yayınları.

Karademir, F. (2019). Türkçe söz varlığı tasnifinde kullanılan bazı terimler üzerine. Journal of Social, Humanities and Administrative Sciences, 5(8), 736-744.

Kaya, N. (2007). Okul sözlüklerinin değerlendirilmesi (1945-2005). (Yayımlanmamış Yüksek Lisans Tezi). İstanbul: Marmara Üniversitesi. 
Mutlu, H. K. (2009). Türkçe öğretiminde sözlükçülük tekniği açısından tematik sözlükler. Turkish Studies, 4(4), 814-822.

Özcan, E. (2019). Türkçe genel sözlük hazırlama süreci üzerine bir araştırma (Yayımlanmamış Doktora Tezi). Ankara: Ankara Üniversitesi Sosyal Bilimler Enstitüsü.

Sayan, P. (2005). 11-14 yaş için hazırlanan okul sözlüklerinde tanımlar üzerine bir araştırma. (Yayımlanmamış Yüksek Lisans Tezi). İstanbul: Marmara Üniversitesi Eğitim Bilimleri Enstitüsü.

Usta, H. İ. (2006). Türkçe sözlük hazırlamada yöntem sorunları. Ankara Üniversitesi Dil ve TarihCoğrafya Fakültesi Dergisi, 46(1), 223-242.

Usta, H. İ. (2010). Sözlükçülük ve sözlük araştırmacılı̆̆ı. Modern Türklük Araştırmaları Dergisi, 7(2), 92-101.

Yalçın, S. K. ve Özek, F. (2006). Söz varlığının temel dil becerilerinin ve akademik disiplinlerin kazanımına olan etkileri. Millî Ĕgitim, 171, 130-139.

Yelbay, Y. (2015). Sözcük bilgisi ve öğretimi (ss. 351-368), Dil Öğretimi (Editör: N. Bekleyen), Ankara: Pegem Akademi Yayınları.

Yılmaz, E. (2017a). Sözlük bilimi üzerine araştırmalar. Ankara: Pegem Akademi Yayınları.

Y1lmaz, E. (2017b). Sözcük eşleştirmeye dayalı (word-match) tanımlar bakımından güncel türkçe sözlük'ün değerlendirilmesi (ss. 202-216), III. Uluslararası Sözlükbilimi Sempozyumu Bildiri Kitabı (Ed. E. Boz vd.). Eskişehir: Osmangazi Üniversitesi Basımevi.

Yılmaz, E. ve Koçmar, Y. (2009). İlköğretim okulları (6, 7, 8. Sinıflar) için hazırlanan türkçe sözlüklerin türkçe ders kitaplarındaki söz varlığını yansıtması bakımından değerlendirilmesi. Sakarya Üniversitesi Eğitim Fakültesi Dergisi, 18, 79-98. 


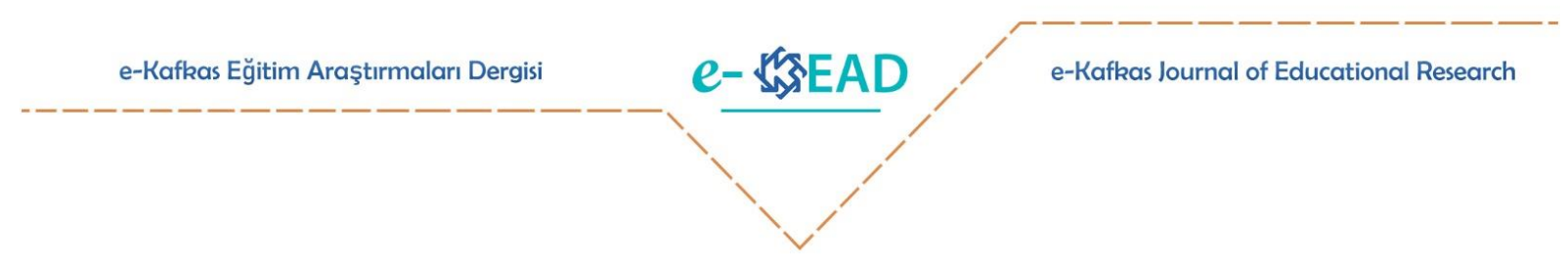

\title{
Formal-Content Features of Education Dictionaries and A Proposal on the Process, Principles and Criteria of Preparing a Turkish School Dictionary in the Context of Problems raised in Academic Studies: Thematic School Dictionaries
}

\begin{abstract}
Ali Göçer
To cite this article: Göçer, A. (2020). Okul sözlüklerinin biçimsel-içerik özellikleri ve akademik çalışmalarda değinilen sorunlar bağlamında Türkçe okul sözlüğü hazırlama süreç, ilke ve ölçütleri üzerine bir öneri: Tematik okul sözlükleri. e- Kafkas Eğitim Araştırmalarl Dergisi, 7, 66-83. doi: 10.30900/kafkasegt.686488
\end{abstract}

Review Article

Received: 07.02.2020

Accepted: 01.04.2020

\section{Introduction}

Today, as in every field, development, change and transformation are rapidly observed in the field of education. In today's world, it is among the top priority competencies to use the information needed, to extract and filter the information obtained, to transfer, to produce new information by blending with the existing information, and most importantly, to display the skills required by using the knowledge locally. The ability to produce information in a time when information is constantly changing and the ability to use the produced information in real life also requires the individual to use the skills of understanding, interpretation, inference and comprehension effectively. The basic power that forms the basis of comprehension and expression skills is the vocabulary possessed. In the enrichment of vocabulary, educational materials used in educational processes play an important role. The most functional and widely used of these materials are dictionaries used to enrich vocabulary.

\section{Formal and Content Features of Dictionaries}

Dictionaries are the basic books of language distant and close, real and metaphor with all its meanings; are made their definitions, their reading, spelling, emphasis, and are specified in the language by including all vocabulary in the language; is shown their place in grammar. In fact, many dictionaries also guide the way of using the language beautifully by including sample sentences and proverbs selected from literary works (Böler, 2006).

Basatemur (2013) states that Boz (2011) ranks among these technical problems as follows:

- The method to be chosen in dictionary preparation,

- For the purpose and target audience,

- Examination of the item heads,

- Ordering the heads of the article,

- Identification of item heads,

- Explanation of sample sentences for the heads of the article,

- Other problems.

Usta (2006) lists the deficiencies and methodological errors that may occur in dictionaries based on the examples he identified in his dictionary review study as follows:

- Being objective or egocentrism

- To follow the agenda or update

- Prepress control 
- Ingredient, substance: wrong, unnecessary, broken / faulty substances, insufficient intersubstance connection, insufficient inter-substance connections

- Wrong etymology

- Identification / Description: wrong, incomplete, inadequate, corrupt, uncertain, unnecessary explanations / definitions.

- Sampling: insufficient, unnecessary / useless sampling.

- The order of meaning is mixed

- Violation of Turkish grammar: in terms of phonetics, semantics, morphology and syntax.

As you can see Boz (2011), Usta (2006), etc., interested in lexicography researchers are listed some technical problems about dictionary preparation, deficiencies that may occur in dictionaries and method errors summaries on basic problems in dictionary preparation as follows:

- The purpose and target audience are not determined well,

- Technical errors in the identification, ordering and identification of the heads of the substance, being objective or egocentrism

-Wrong, unnecessary, damaged / defective items,

- Insufficient links between substance and substance

- Wrong, incomplete, inadequate, uncertain, unnecessary explanations / definitions.

- Insufficient, unnecessary / useless sampling.

\section{Approaches and Elements in Dictionary Preparation}

In preparing dictionaries, there are generally two types of approaches: The first one is dictionaries prepared with an approach that includes scientific and morphological conditions while describing the words. In the dictionaries prepared with the second approach, objects are described with encyclopedic definitions (Günay, 2007: 36).

\section{Stages of Dictionary Preparation Process}

Like McGregor, Svensén (1993) divides the process of dictionary creation into two stages (Act. Golynskaia, 2017: 35):

1. Planning: a) needs assessment, b) pre-planning, c) preliminary analysis, d) reviewing the project plan, e) preparing a sample section, f) finalization of the final plan.

2. Application: a) collecting and selecting materials, b) drafting, c) reviewing the text, d) production (including correction reading).

\section{Purpose and Scope}

The purpose of this research is to give a general overview of school dictionaries in terms of structure, functionality and preparation criteria and is to point out the need to prepare sequential thematic Turkish dictionaries at first, middle and high school levels that can serve as the basic tool that can help students gain vocabulary appropriate to their levels. For this purpose, a literature review on school dictionaries was carried out. The information obtained through the literature review was tried to be revealed within the scope of the research. In addition, it is aimed to put forward a modeling proposal on the preparation of thematic Turkish dictionaries at primary, secondary and high school levels.

\section{Method}

This study is a scanning, review and compilation study based on literature review within the framework of qualitative research approach. In this framework, are emphasized the formal-content features of educational dictionaries and the process, principles and criteria of preparing a school dictionary with the formal-content features of educational dictionaries in the context of the issues raised in the literature and especially in postgraduate theses.

\section{Discussion, Conclusion and Recommendations}

School dictionaries are the main source of reference for students to have a rich vocabulary. School dictionaries are one of the first and main reference sources used from past to present as a pedagogical tool. Starting from the first of the educational levels, it is an information source that serves educational at all levels and an application tool that provides some linguistic and mental skills. 
Dictionaries, which are one of the basic reference tools in the education process, must have some features in order to be a functional tool with educational value. This study focuses on the structure, functionality, features and preparation criteria of the school dictionaries in the educational context, and it is recommended to prepare a consecutive school dictionary that can be used in the thematic structure at the primary, middle and high school level.

While preparing school dictionaries, considering the developmental characteristics of the students studying within the scope limitation and the education level addressed by the dictionary, it is an educational imperative to prepare consecutive thematic dictionaries specific to each education level as exemplified in the following namings. What is meant by the term 'thematic' is not only a framework created within the scope of the themes in Turkish textbooks, but also the idiom, proverbs, dilemmas, stereotypes, etc. required by the grade levels at the relevant level. it can be considered as a framework in which language unions are also included.

Thematic Turkish Dictionary for Primary School Students (Printed)

Thematic Turkish Dictionary for Secondary School Students (Printed + Electronic)

Thematic Turkish Dictionary (Electronic) for High School Students or

Thematic Turkish Dictionary: Primary School Level (Printed)

Thematic Turkish Dictionary: Secondary School Level (Printed + Electronic)

Thematic Turkish Dictionary: High School Level (Electronic). 